\title{
In Vitro Cytotoxic Effect Evaluation of Dioscorea communis (L.) Caddick \& Wilkin Rhizome and Stem Extracts on Hepatocellular Carcinoma Cells ${ }^{\dagger}$
}

\author{
Ünal Egeli 1,*, Beste Yurdacan 1, Huzeyfe Huriyet 1, Gamze Güney Eskiler 1, Işıl Ezgi Eryılmaz 1, \\ Tolga Cavas ${ }^{1}$, Gülşah Çeçener ${ }^{1}$, Hulusi Malyer ${ }^{2}$ and Berrin Tunca ${ }^{1}$ \\ 1 Medical Biology Department, Faculty of Medicine, Uludag University, Bursa 16059, Turkey; \\ gguneyy@gmail.com (G.G.E.); tcavas@gmail.com (T.C.) \\ 2 Botany Department, Faculty of Science and Art, Uludag University, Bursa 16059, Turkey, \\ malyer@uludag.edu.tr \\ * Correspondence: egeli@uludag.edu.tr; Tel.: +90-224-295-41-51 \\ + Presented at the 2nd International Conference on Natural Products for Cancer Prevention and Therapy, \\ Kayseri, Turkey, 8-11 November 2017.
}

Published: 15 November 2017

\begin{abstract}
Plant kingdom still has an important potential for cancer treatment as natural source of numerous active small molecules with various pharmacological properties. The aim of this study was to firstly investigate in vitro cytotoxic activities rhizome and stem extracts of Dioscorea communis (L.) Caddick \& Wilkin (named "Sarmaş1k" locally) collected in Turkey. The cytotoxic and genotoxic effects at different concentrations $(50-500 \mu \mathrm{g} / \mathrm{mL})$ of each extract was determined using WST-1 proliferation and Comet assay against hepatocellular carcinoma (HepG2 and SNU-449) cell lines compared with HUVEC cells. The morphological changes of these cells treated with D. communis extracts was screened by acridine orange/ethidium bromide staining. We found that the petroleum ether rhizome extracts showed higher cytotoxic and genotoxic activity than stem extracts to all cell lines in a dose and time dependent manner $(p<0.05)$. These extracts induced apoptosis and DNA damage at $500 \mu \mathrm{g} / \mathrm{mL}$ after $72 \mathrm{~h}$ exposure. However, these extracts exhibited significant cytotoxic, genotoxic and apoptotic damage against HUVEC cells. As a result, our data suggest that the active chemical constituent(s) in different part of plants and their mechanisms of inducing apoptosis and DNA damage should be determined in further investigations by in vitro studies compared with control cells.
\end{abstract}

Keywords: hepatocellular carcinoma; plant extracts; Dioscorea communis; apoptosis

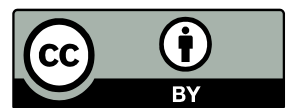

(C) 2017 by the authors. Licensee MDPI, Basel, Switzerland. This article is an open access article distributed under the terms and conditions of the Creative Commons Attribution (CC BY) license (http://creativecommons.org/licenses/by/4.0/). 